\title{
A COMPARATIVE STUDY OF EDUCATORS' VIEWS ON ADVANTAGES AND DISADVANTAGES OF OPEN EDUCATIONAL RESOURCES IN HIGHER EDUCATION
}

\author{
Julija Melnikova
}

Klaipeda University, Lithuania

\section{Jeḷena Zaščerinska}

Latvia

\section{Andreas Ahrens}

Hochschule Wismar, Germany

\section{Ramar Hariharan}

Dr. Sivanthi Aditanar College of Education, India

\section{Otilia Clipa}

Stefan cel Mare University Suceava, Romania

\section{Daria Sowinska-Milewska}

Non-Governmental Organisation of Trainers' Association, Poland

\section{Natalia Andreeva}

Immanuel Kant Baltic Federal University, Russian Federation

\begin{abstract}
The aim of the contribution is to analyze advantages and disadvantages of open educational resources (OER) in higher education underpinning elaboration of a new research question. Comparative study was applied. The study was carried out in February 2016. Data was collected via semi-structured interviews. The sample included seven educators from different countries. The data were processed via structuring and summarizing content analysis. The respondents' views are homogeneous. A new research question is formulated. Directions of further research are proposed.

Keywords: advantages, comparative study, disadvantages, educators' view, higher education, open educational resources.
\end{abstract}


Julija Melnikova, Jel̦ena Zaščerinska, Andreas Ahrens, Ramar Hariharan, Otilia Clipa, Daria Sowinska-Milewska, Natalia Andreeva. A Comparative Study of Educators' Views on Advantages and Disadvantages of Open Educational Resources in Higher Education

\section{Introduction}

The paradigm in higher education changes from e-learning to open learning. Open learning is centred on open educational resources (OER). Open educational resources (OER) ensure educational environment in higher education for closer inter-connections between students, educators, researchers and other participants. Open educational resources (OER) have attracted a lot of research interest. Advantages and disadvantages of open educational resources (OER) are widely discussed. On the one hand, Open Educational Resources (OER) are the right way which enables free and accessible education to everyone and access to knowledge as public good via cherishing the culture of participation, collaboration and sharing and with an open access to scientific information it brings a notable contribution in knowledge society development (Kurelovic, 2016). On the other hand, small countries which use a non-English language, have limited resources and support to customize and create Open Educational Resources (OER), their educational practice is founded on traditional teaching methods with occasional use of digital contents and ICT (Kurelovic, 2016). However, little attention has been paid to a comparative study of educators' views on open educational resources (OER). Such a lacuna in higher education has to be filled in. The research question is as follows: What are advantages and disadvantages of open educational resources (OER) in higher education? The aim of the research is to analyze advantages and disadvantages of open educational resources (OER) in higher education underpinning elaboration of a new research question on use of open educational resources (OER) in higher education. The present research involves a process of analysing the meaning of such key concepts as open educational resources (OER) and view. Moreover, the study demonstrates how the key concepts are related to the idea of higher education. The study presents how the steps of the process are related: open educational resources (OER) $\rightarrow$ empirical study within multicultural environments $\rightarrow$ conclusions. The methodological foundation of the present research is formed by the SystemConstructivist Theory. The System-Constructivist Theory and, consequently, System-Constructivist Approach to learning introduced by Reich (Reich, 2005) emphasizes that human being's point of view depends on the subjective aspect (Maslo, 2007) as experience plays the central role in the knowledge construction process (Maslo, 2007). Therein, the subjective aspect of human being's point of view is applicable to the present research. Exploratory research was employed in the present research (Phillips, 2006). Exploratory research is aimed at developing hypotheses, which can be tested for generality in following empirical studies (Mayring, 2007). The exploratory methodology proceeds from exploration in Phase 1 through analysis in Phase 2 to hypothesis development in Phase 3. 


\section{Conceptual Framework}

The present part of the contribution provides a conceptual framework on advantages and disadvantages of open educational resources (OER) in higher education. A framework means the specific viewpoint (Ahrens \& Zaščerinska, 2014) on a phenomenon. In research, frameworks are differentiated into theoretical and conceptual. A theoretical framework includes the combination of concepts together with their definitions as well as existing theory applied to a particular study. A concept is defined to be a verbal abstraction drawn from observation of a number of specific cases (Watt \& van den Berg, 2002). Hence, a conceptual framework means the unity of concepts that are used for a particular study (Ahrens \& Zaščerinska, 2014). Concepts can be expressed in a variety of forms such as a term, image, etc. In the present contribution, term means a word or a combination of words used to describe a phenomenon. Further on, the term definition is considered as the statement of the phenomenon notion, elements and process (Ahrens, Zaščerinska, \& Andreeva, 2013).

By open educational resources (OER), ,teaching, learning and research materials in any medium, digital or otherwise, that reside in the public domain or have been released under an open license that permits no-cost access, use, adaptation and redistribution by others with no or limited restrictions" (United Nations Educational, Scientific and Cultural Organization (UNESCO), 2002) is meant. Advantages are identified as any trait, feature or aspect that gives an individual, entity or any other thing a more favorable opportunity for success (Business Dictionary, 2016a). In contrast, disadvantages are identified as any trait, feature or aspect that does not give an individual, entity or any other thing a more favorable opportunity for success (Business Dictionary, 2016b). Open Educational Resources (OER) are favourable for A) reducing the gap between different strata of society and between countries, improve the quality of education, accelerate the knowledge flow and increase the number of people involved in the educational process (mostly informal and lifelong), B) Open Educational Resources (OER) using, reusing, editing, remixing and re-purposing without restrictions, C) personalised learning, D) promoting equity by increasing the availability of knowledge as individuals may learn anytime, anywhere, with the support of anyone, using any device, E) individualized learning in accordance with learners' learning style, F) learners' more active participation in educational process through a collaboration in virtual communities of learning, $G$ ) teachers' comparison of their own teaching materials with other teachers all around the world, they can learn how to release their work under an open license and to improve quality of teaching practice and encourage pedagogical innovation (Kurelovic, 2016), and $\mathrm{H}$ ) reducing the cost of accessing educational materials (McGreal, Kinuthia, \& Marshall, 2013). Open Educational Resources (OER) 
Julija Melnikova, Jel̦ena Zaščerinska, Andreas Ahrens, Ramar Hariharan, Otilia Clipa, Daria Sowinska-Milewska, Natalia Andreeva. A Comparative Study of Educators' Views on Advantages and Disadvantages of Open Educational Resources in Higher Education

require such more efforts in (Kurelovic, 2016) increase of recognisability of the Open Educational Resources (OER) repositories, ensuring quality of content and development of online collaborative communities, use of suitable licences for teaching materials exchange at the global level and through formal channels, an uncertainty regarding the copyright on educational content and sharing of Open Educational Resources (OER) across languages and cultures.

Individual's view is based on awareness and attitudes (Bel̦ickis, Blūma, Koķe, Markus, Skujinga, \& Šalme, 2000). Analysis of this definition allows identifying such a new definition of view as individual's view on a phenomenon is based on his/her knowledge, skills and attitudes (Ahrens, Zaščerinska, Hariharan, \& Andreeva, 2016). As educators' view is based on educators' knowledge, skills and attitudes, educators' competence serves as an indicator of educators' view on open educational resources (OER) in higher education. Competence consists of knowledge, skills and attitudes. The elements of competence, namely knowledge, skills and attitude, are inter-related (Ahrens \& Zaščerinska, 2015). Educators' negative attitude fails to promote the increase in the level of learners' knowledge and skills as well as competence, in general (Ahrens \& Zaščerinska, 2015). In contrast, educators' positive attitude ensures the enrichment of the level of learners' knowledge and skills as well as competence (Ahrens \& Zaščerinska, 2015). It should be noted that knowledge is presented by concepts (Žogla, 2001). Skill is an ability to act in accordance with the required quality and volume (Bel̦ickis, Blūma, Koḳe, Markus, Skujiṇa, \& Šalme, 2000). Attitude is defined as an individual combination of evaluative judgments about a phenomenon (Ahrens \& Zaščerinska, 2015). In pedagogy, the terms competence and experience are used synonymously (Ahrens \& Zaščerinska, 2015). As experience plays the central role in a knowledge construction process on open educational resources (OER) in higher education, the subjective aspect of human being's point of view highlighted by the System-Constructivist Theory is considered within the present research.

\section{Empirical Results}

The present part of the contribution demonstrates the design of the empirical study, results of the empirical study and findings of the study.

The design of the empirical study comprises the purpose and question, sample and methodology of the present empirical study. The guiding research question is as follows: what are educators' views on open educational resources (OER)? The purpose of the empirical study is to analyze educators' views on open educational resources (OER). The sample of the present empirical study carried out in February 2016 was composed of seven educators from seven different countries, namely Lithuania, Latvia, Germany, India, Romania, Poland and 
Russian Federation. All the respondents are educators in different sciences such as philology, sociology, pedagogy, management and engineering. As the respondents with different cultural backgrounds and diverse educational approaches were chosen, the sample was multicultural. Educators' different cultural backgrounds and diverse educational approaches emphasize the significance of each educator's contribution to the analysis (Luka, Ludborza, \& Maslo, 2009) of open educational resources (OER) in higher education. All the seven participants had received extensive teaching and training experience in higher education. Thus, the group (age, field of study and work, mother tongue, etc.) is heterogeneous.

The sample of seven respondents involved one educator from Lithuania, one educator from Latvia, one educator from Germany, one educator from India, one educator from Romania, one educator from Poland, and one educator from Russian Federation. In order to save the information of the present research confidential, the respondents' names and surnames were coded as follows: the educator from Lithuania was given the code R1 (Respondent 1), the educator from Latvia was pointed as R2 (Respondent 2), the educator from Germany was coded as R3 (Respondent 3), the educator from India was identified as R4 (Respondent 4), the educator from Romania was shown as R5 (Respondent 5), the educator from Poland had the code R6 (Respondent 6), and the educator from Russian Federation was indicated as R7 (Respondent 7).

The interpretive paradigm was used in the empirical study. The interpretive paradigm aims to understand other cultures, from the inside through the use of ethnographic methods such as informal interviewing and participant observation, and establishment of ethically sound relationships (Taylor \& Medina, 2013). Interpretative paradigm is characterized by the researcher's practical interest in the research question (Cohen, Manion, \& Morrison, 2007). The researcher is the interpreter.

Comparative study as a qualitative research design has been employed (Flick, 2004). The exploratory type of the comparative study has been applied (Phillips, 2006). The exploratory type of the comparative study aims to generate new hypotheses and questions (Phillips, 2006). The exploratory methodology proceeds as follows (Phillips, 2006): 'conceptualisation' in Phase 1, detailed description of educational phenomena in the countries to be investigated, with full attention paid to the local context in terms of its historical, geographical, cultural, political, religious, and linguistic (etc.) features in Phase 2, the data collection in Phase 3, explanation through the development of hypotheses in Phase 4, reconsideration of the initial questions and application of the findings to other situations in Phase 5. The qualitatively oriented empirical study allows the construction of only few cases (Mayring, 2004). Moreover, the cases themselves are not of interest, only the conclusions and transfers we can draw from these 
Julija Melnikova, Jel̦ena Zaščerinska, Andreas Ahrens, Ramar Hariharan, Otilia Clipa, Daria Sowinska-Milewska, Natalia Andreeva. A Comparative Study of Educators' Views on Advantages and Disadvantages of Open Educational Resources in Higher Education

respondents (Flyvbjerg, 2006). Selecting the cases for the case study comprises use of information-oriented sampling, as opposed to random sampling (Flyvbjerg, 2006). This is because an average case is often not the richest in information. In addition, it is often more important to clarify the deeper causes behind a given problem and its consequences than to describe the symptoms of the problem and how frequently they occur (Flyvbjerg, 2006). Random samples emphasizing representativeness will seldom be able to produce this kind of insight; it is more appropriate to select some few cases chosen for their validity. Semi-structured interviews served as a means of data collection. Semi-structured interviews were used as the researchers had obtained the initial knowledge on the research field (Kroplijs \& Raščevka, 2004). The semi-structured interviews implied the following question: What are advantages and disadvantages of open educational resources (OER) in higher education? The collected data were processed via structuring content analysis focused on identifying advantages and disadvantages of open educational resources (OER). Table 1 summarizes the results of the semistructured interviews.

Table 1 Summary of the semi-structured interviews

\begin{tabular}{|c|c|c|}
\hline $\begin{array}{l}\text { Respon- } \\
\text { dent }\end{array}$ & $\begin{array}{c}\text { Advantages of open educational } \\
\text { resources (OER) }\end{array}$ & $\begin{array}{c}\text { Disadvantages of open educational } \\
\text { resources (OER) }\end{array}$ \\
\hline $\mathbf{1}$ & $\begin{array}{l}\text { - } \text { OER is } \\
-\quad \text { Opportunity for educators to get } \\
\text { concentrated information, } \\
\text { relevant materials, methodic } \\
\text { support etc. } \\
-\quad \text { Opportunity to share the } \\
\text { knowledge and expertise on local, } \\
\text { national and international level; } \\
-\quad \text { Opportunity to develop } \\
\text { professional competences, self- } \\
\text { education; } \\
-\quad \text { Opportunity to disseminate } \\
\text { information; } \\
\text { - Opportunity to collaborate with } \\
\text { partners. }\end{array}$ & $\begin{aligned}- & \text { OER does not } \\
- & \text { Provide tools for users' } \\
& \text { communication on various topics; } \\
- & \text { Ensure possibility to vote for best } \\
& \text { materials; } \\
- & \text { Create users' friendly } \\
& \text { environment and technical tools. }\end{aligned}$ \\
\hline 2 & $\begin{array}{l}\text { - OER ensures a variety of teaching } \\
\text { and learning materials } \\
\text { - } \\
\text { Teacher can re-use OER for other } \\
\text { groups of learners } \\
-\quad \text { Learners can access OER any } \\
\text { time and any location where the } \\
\text { Internet is available }\end{array}$ & 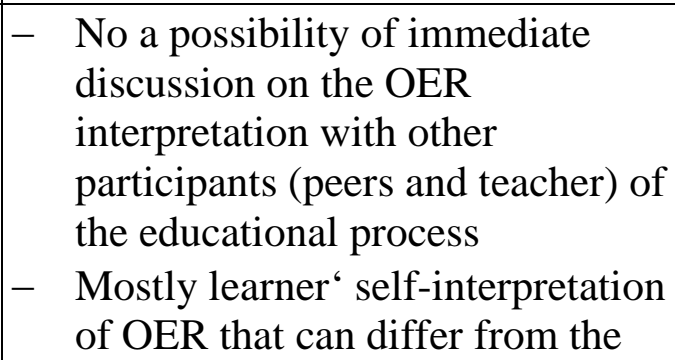 \\
\hline
\end{tabular}




\begin{tabular}{|c|c|c|c|}
\hline & & & $\begin{array}{l}\text { others' interpretation that, in turn, } \\
\text { sometimes delays the } \\
\text { implementation of a task. } \\
\text { - Learners' time management }\end{array}$ \\
\hline 3 & & $\begin{array}{l}\text { Reusable materials, } \\
\text { Access anytime from anywhere, } \\
\text { Possibility to combine studies } \\
\text { with other activities }\end{array}$ & $\begin{array}{ll}- & \text { No direct access to the tutor, } \\
- & \text { No direct access to other students } \\
& \text { in order to share their experience, } \\
\text { - } & \text { Time Management }\end{array}$ \\
\hline 4 & & $\begin{array}{l}\text { Providing learning materials for } \\
\text { professional programmes such as } \\
\text { Bachelor's and Master's degree } \\
\text { programmes in library and } \\
\text { information sciences, } \\
\text { Production of a portal for the } \\
\text { educational community to share } \\
\text { information, course content, and } \\
\text { make accessible quality distance } \\
\text { education learning products and } \\
\text { services, } \\
\text { Using existing resources, develop } \\
\text { reusable learning objects as } \\
\text { „cognitive Bricks between the } \\
\text { institutions”, } \\
\text { Developing collections of science } \\
\text { experiments and processes, and } \\
\text { the resources of art galleries and } \\
\text { historical archives, } \\
\text { Developing the international } \\
\text { intellectual resource that is } \\
\text { constituted by scientists and } \\
\text { professors who are currently } \\
\text { under-used in their present } \\
\text { national infrastructure, } \\
\text { Developing courses in the field of } \\
\text { continuing education, } \\
\text { Collaborating with other countries } \\
\text { in the development of case studies } \\
\text { in international business } \\
\text { (including health education), for } \\
\text { example in the transition from } \\
\text { traditional to modern business } \\
\text { structures, } \\
\text { Provide a test/evaluation } \\
\text { environment for open courseware }\end{array}$ & $\begin{array}{l}\text { - Not surprisingly, the access } \\
\text { limitations most commonly } \\
\text { reported are lack of adequate } \\
\text { bandwidth, a shortage of } \\
\text { computers, and the need for } \\
\text { training in ICT. Inadequate local } \\
\text { telecommunication infrastructure, } \\
\text { sometimes including regulatory } \\
\text { policy that has the effect of } \\
\text { keeping costs high and access } \\
\text { limited, is also a recurring issue. } \\
\text { - } \\
\text { In some institutions computer } \\
\text { access is limited to faculty and } \\
\text { graduate students, and often it is } \\
\text { inadequate even for this relatively } \\
\text { small group of users. } \\
\text { - Language can also be a } \\
\text { constraint. Sometimes the } \\
\text { language of instruction is not the } \\
\text { language of the Web. } \\
\text { Multilingualism: It functions as a } \\
\text { limiting factor [since] institutions } \\
\text { feel that it is inappropriate and } \\
\text { improper to be present on the web } \\
\text { only in Tamil or Telugu, so they } \\
\text { spend a lot of energy and } \\
\text { resources trying to have the } \\
\text { materials in their mother tongue. } \\
\text { For some, there is a reported } \\
\text {,non-readiness” to use resources } \\
\text { like Open Educational Resources } \\
\text { (OER). }\end{array}$ \\
\hline
\end{tabular}


Julija Melnikova, Jel̦ena Zaščerinska, Andreas Ahrens, Ramar Hariharan, Otilia Clipa, Daria Sowinska-Milewska, Natalia Andreeva. A Comparative Study of Educators' Views on Advantages and Disadvantages of Open Educational Resources in Higher Education

\begin{tabular}{|c|c|c|c|}
\hline & & $\begin{array}{l}\text { programmes, } \\
\text { Publish links to pages created by } \\
\text { faculty worldwide who are using } \\
\text { the Web to deliver course } \\
\text { materials in different languages }\end{array}$ & \\
\hline 5 & & $\begin{array}{l}\text { Learners and teachers can access } \\
\text { e-tools in any location and } \\
\text { conditions, } \\
\text { Teachers can use and re-use all } \\
\text { materials from time to time, } \\
\text { Possible to use for team-teaching } \\
\text { and team-learners }\end{array}$ & $\begin{array}{l}\text { is not a direct \& affective } \\
\text { communication, } \\
\text { - } \text { planning a time slot for learning } \\
\text { is difficult, } \\
\text { - has no an affective feed-back in } \\
\text { real time. }\end{array}$ \\
\hline 6 & a) & $\begin{array}{l}\text { we can learn from everybody all } \\
\text { over the world, } \\
\text { we can find even every needed } \\
\text { information just from a computer } \\
\text { via a web site } \\
\text { teacher can offer students much } \\
\text { more materials, books, video etc. } \\
\text { it can help in learning and } \\
\text { teaching }\end{array}$ & $\begin{array}{l}\text { a) quality - in open resources, } \\
\text { especially international - we } \\
\text { sometimes know nothing about } \\
\text { quality, authors' experience; } \\
\text { without guide/leader it is very } \\
\text { difficult to work with OER, } \\
\text { b) wi-fi and other technical } \\
\text { difficulties, } \\
\text { c) too much data causes } \\
\text { discouragement and decline in } \\
\text { motivation, } \\
\text { d) problem of copyright - authors } \\
\text { sometimes do not want ,to open” } \\
\text { his work, book, etc. People } \\
\text { working not at university or } \\
\text { school in fact do not want to } \\
\text { show even presentations or } \\
\text { articles because of copyright }\end{array}$ \\
\hline 7 & & $\begin{array}{l}\text { Easy access to varied on-line } \\
\text { data; } \\
\text { Latest developments in medical } \\
\text { sciences and research results } \\
\text { available on-line help in training } \\
\text { better specialists for the sphere of } \\
\text { public health; } \\
\text { Accessibility of research results } \\
\text { on-line can promote professional } \\
\text { collaboration among students, } \\
\text { thus contributing to better } \\
\text { qualification. }\end{array}$ & $\begin{array}{l}\text { - Questionable reliability of sources } \\
\text { and materials at times; } \\
\text { - The issue of copyright; } \\
\text { - Poor guidance through some } \\
\text { resources }\end{array}$ \\
\hline
\end{tabular}


The collected data were processed via structuring and summarizing content analysis. The structuring content analysis (Mayring, 2004) of the data demonstrates that the educators' views on advantages and disadvantages of open educational resources (OER) have similarities. The respondents outlined the advantages of open educational resources (OER) such as re-use of open educational resources (OER), use of open educational resources (OER) at any time and use of open educational resources (OER) at any location where the Internet is available. The respondents identified such disadvantages of open educational resources (OER) as technical difficulties to reach OER due to limitations of open educational resources (OER) access, Internet access and computer access; limited open educational resources (OER) interpretation, open educational resources (OER) availability in a native language as well as quality of open educational resources (OER). Summarizing content analysis (Mayring, 2004) of the data reveals that the respondents' views on open educational resources (OER) are homogeneous.

\section{Conclusions}

The empirical findings of the research allow drawing the conclusions on educators' homogeneous view on open educational resources (OER) in higher education. A new research question has been formulated: What are criteria of qualitative open educational resources (OER) in higher education?

The present research has limitations. The inter-connections between open education resources (OER), advantages and disadvantages, view, educators and higher education have been set. Another limitation is the empirical study conducted by involving educators only.

Further research tends to focus on empirical studies to compare teacher trainers' and educators' views on open educational resources (OER). The search for relevant methods for evaluation of advantages and disadvantages of open educational resources (OER) in higher education is proposed. Empirical studies to compare students and educators' opinions on educational resources (OER) in higher education are emphasized. And a comparative research of more countries could be carried out, too.

\section{References}

Ahrens, A., \& Zaščerinska, J. (2015). A Comparative Study of Business and Engineering Students' Attitude to Mobile Technologies in Distance Learning. In: P. Ordonez De Pablos, R. D. Tennyson \& M. D. Lytras, Assessing the Role of Mobile Technologies and Distance Learning in Higher Education, Chapter 2, p. 29-59. IGI-Global.

Ahrens, A., \& Zaščerinska, J. (2014). A Framework for Selecting Sampe Size in Educational Research on e-Business Application. In: M.S. Obaidat, A. Holzinger, M. van Sinderen, \& 
Julija Melnikova, Jel̦ena Zaščerinska, Andreas Ahrens, Ramar Hariharan, Otilia Clipa, Daria Sowinska-Milewska, Natalia Andreeva. A Comparative Study of Educators' Views on Advantages and Disadvantages of Open Educational Resources in Higher Education

P. Dolog (Eds), In Proceedings of ICE-B 2014 11th International Conference on EBusiness, pp. 31-38. Portugal: SciTePress.

Ahrens, A., Zaščerinska, J., \& Andreeva, N. (2013). Engineering Students ‘ Blended Learning in Higher Education. Proceedings of International Scientific Conference Society, Integration, Education Volume 1, 34-44. Rēzekne: Rēzeknes Augstskolas Izdevniecība.

Ahrens, A., Zaščerinska, J., Hariharan, R., \& Andreeva, N. (2016). Educators' Opinion on Webinars in Higher Education. Proceedings of the International Scientifical Conference Society, Integration, Education, Volume 1, pp. 15-27. - Rezekne: RAT.

Belickis, I., Bluma, D., Koke, T., Markus, D., Skujina, V., (vad.) \& Šalme, A. (2000). Pedagogijas terminu skaidrojošā vārdnīca. Termini latviešu, angḷu, vācu, krievu valodā. Rīga: "Zvaigzne ABC”, 2000. — 248 lpp.

Business Dictionary. (2016a). Advantage. http://www.businessdictionary.com/definition/ advantage.html.

Business Dictionary. (2016b). Disadvantage. http://www.businessdictionary.com/definition/ disadvantage.html.

Cohen, L., Manion, L., \& Morrison, K. (2007). Research Methods in Education. Routledge Education.

Flick, U. (2004). Design and Process in Qualitative Research. In U. Flick, E. Von Kardoff \& I. Steine (Eds), A Companion to Qualitative Research (pp. 146-152). Glasgow: SAGE.

Flyvbjerg, B. (2006). Five Misunderstandings About Case-Study Research. Qualitative Inquiry, 12 (2), 219-245.

Kroplijs, A., \& Rascevska, M. (2004). Kvalitatīvās pētniecības metodes sociālajās zinātnēs. Rīga: RaKa.

Kurelovic, E. K. (2016). Advantages and limitations of usage of open educational resources in small countries. International Journal of Research in Education and Science (IJRES), 2 (1), 136-142.

Luka, I., Ludborza, S., \& Maslo, I. (2009). Effectiveness of the use of more than two languages and quality assurance in European interuniversity master studies. Paper presented at the European Conference on Educational Research, University of Vienna, September 28-30, 2009.

Maslo, E. (2007). Transformative Learning Space for Life-Long Foreign Languages Learning. In: International Nordic-Baltic Region Conference of FIPLV Innovations in Language Teaching and Learning in the Multicultural Context (pp. 38-46), 15-16 June 2007, Riga.

Mayring, P. (2004). Qualitative Content Analysis. Flick, U., von Kardoff, E., Steinke, I. (Eds.) A Companion to Qualitative Research, pp. 266-269. SAGE, Glasgow, UK.

Mayring, P. (2007). On Generalization in Qualitatively Oriented Research. Forum Qualitative Sozialforschung / Forum: Qualitative Social Research, 8 (3), Art. 26 (p. 1-8).

McGreal, R., Kinuthia, W., \& Marshall, S. (2013). Open Educational Resources: Innovation, Research and Practice. Vancouver: Commonwealth of Learning \& Athabasca Uni.

Phillips, D. (2006). Comparative Education: method. Research in Comparative and International Education, Volume 1, Number 4, 2006, 304-319.

Reich, K. (2005). Systemisch-konstruktivistische Pädagogik. Weinheim:Beltz, 2005, 299 p.

Taylor, P. C., \& Medina, M. N. D. (2013). Educational Research Paradigms: From Positivism to Multiparadigmatic. The Journal of Meaning-Centered Education. 1.

United Nations Educational, Scientific and Cultural Organisation (UNESCO). (2002). Forum on the Impact of Open Courseware for Higher Education in Developing Countries. Final report. Paris, 1-3 July 2002. 
SOCIETY. INTEGRATION. EDUCATION

Proceedings of the International Scientific Conference. Volume I, May $26^{\text {th }}-27^{\text {th }}$, 2017. 294-304

Watt, J. H., \& van den Berg, S. (2002). Research Methods For Communication Science. http://www.cios.org/readbook/rmcs/rmcs.htm.

Žogla, I. (2001). Mūsdienu mācību teorijas problēmas. Skolotājs Nr. 45/2001 (4.-7. lpp). Rīga: RaKa. (in Latvian). 